This manuscript has been submitted for publication in the journal CHEMICAL GEOLOGY. Please note that, despite having undergone two rounds of peer-review at the journal EARTH AND PLANETARY SCIENCE LETTERS, the manuscript has yet to be formally accepted for publication. Subsequent versions of this manuscript may have slightly different content. Please feel free to contact any of the authors; we welcome feedback 


\title{
Oxidized Mantle Sources of HIMU and EM-type Ocean Island Basalts
}

\author{
Robert W. Nicklas ${ }^{1 *}$, Rachel K. M. Hahn ${ }^{1}$, Lori N. Willhite ${ }^{2}$, Matthew G. Jackson ${ }^{3}$, \\ Vittorio Zanon ${ }^{4}$, Ricardo Arevalo Jr. ${ }^{2}$ and James M.D. Day ${ }^{1}$
}

${ }^{1}$ Scripps Institution of Oceanography, University of California San Diego, La Jolla, CA, 92093, USA

${ }^{2}$ Department of Geology, University of Maryland College Park, College Park, MD, 20742, USA

${ }^{3}$ Department of Earth Science, University of California Santa Barbara, Santa Barbara, CA, 93106, USA

${ }^{4}$ Instituto de Investigação em Vulcanologia e Avaliação de Riscos, Universidade dos Açores, Rua Mãe de Deus, 9500-321 Ponta Delgada, Portugal

*Corresponding author: R. Willie Nicklas: rnicklas@ucsd.edu

5653 Words (Abstract 231, Supplement 2189), 82 References, 3 Figures, 4 Tables

For submission to Chemical Geology

$8 / 31 / 2021$ 


\section{Abstract:}

Oxygen fugacity $\left(\mathrm{fO}_{2}\right)$ is a fundamental variable in igneous petrology with utility as a potential tracer of recycled surficial materials in the sources of mantle-derived lavas. It has been postulated that ocean island basalts (OIB) have elevated $\mathrm{fO}_{2}$ relative to mid-ocean ridge basalts (MORB) owing to more oxidized source regions. To clarify this issue, trace-element systematics of olivine grains are reported from OIB lavas with HIMU (high- $\mu$; Mangaia, Canary Islands), enriched mantle (EM; Samoa; São Miguel, Azores Islands) and depleted MORB mantle (DMM; Pico, Azores) Sr-Nd-Pb-Os isotopic signatures, to constrain the $\mathrm{fO}_{2}$ of each magmatic system. Despite sampling distinct mantle reservoirs based on radiogenic isotope systematics, these OIB suites show similar $f_{2}$, ranging from +1.5 to $+2.9 \Delta \mathrm{FMQ}$, with an average of $2.0 \pm 0.7 \Delta \mathrm{FMQ}$, significantly higher than MORB at $+0.6 \pm 0.2 \Delta \mathrm{FMQ}$ using the same oxybarometer. OIBs show no correlation between $\mathrm{fO}_{2}$ and bulk rock isotopic ratios or parental magma compositions. The lack of correlations with isotopic signatures likely results from radiogenic isotope signatures being hosted in volumetrically minor trace element enriched mantle lithologies, while $\mathrm{fO}_{2}$ reflects the volumetrically dominant mantle component. Higher $\mathrm{fO}_{2}$ in OIB relative to MORB implies a uniformly oxidizing plume source mantle that may be the result of either a common oxidized oceanic crust-rich reservoir parental to all modern plume lavas, or preservation of un-degassed and oxidized mantle domains formed early in Earth history.

\section{Introduction}

Oxygen fugacity $\left(\mathrm{fO}_{2}\right)$ is an intensive variable in igneous petrology that controls the geochemical behavior of redox-sensitive elements such as $\mathrm{Fe}, \mathrm{V}, \mathrm{Cr}, \mathrm{S}, \mathrm{C}$ and $\mathrm{H}$. It is defined as 
23 the chemical potential of molecular oxygen $\left(\mathrm{O}_{2}\right)$ in equilibrium with an igneous system and, like

24 all equilibria, oxygen fugacity depends on temperature and pressure. It is therefore normally

25 discussed in igneous petrology relative to mineral redox buffers, with the most common being

26 the fayalite-magnetite-quartz, or FMQ buffer (Lindsley, 1991). Oxygen fugacity varies significantly

27 in natural Earth systems by nine orders of magnitude, from the reduced metallic core to an atmosphere that contains $\sim 20 \%$ molecular $\mathrm{O}_{2}$. Igneous systems also show large variations in $\mathrm{fO}_{2}$, with arc basalts and alkaline continental basalts showing systematically higher $\mathrm{fO}_{2}$ relative to plume and ridge basalts (Carmichael, 1991; Brounce et al. 2014). Oxygen fugacity in arc basalts is elevated by $\sim+1$ to $+5 \log$ units $\Delta \mathrm{FMQ}$ above ambient mantle, although it is currently debated whether the high value of arc basalts results from subduction-related metasomatism of their mantle source, or from differentiation and degassing processes (Lee et al. 2005; Kelley and Cottrell, 2009; Brounce et al. 2014; Tang et al. 2018). volcanic glasses coupled with the experimental formulation of Kress and Carmichael (1991). The

$37 \mathrm{Fe}^{+3} / \Sigma \mathrm{Fe}$ ratio of volcanic glasses is determined in several ways, including wet chemistry and Mössbauer spectroscopy. X-ray Absorbance Near-Edge Spectroscopy (XANES) has recently allowed for high spatial resolution coupled with relatively fast sample throughput (Cottrell et al. 2011; 2013; Moussallam et al. 2014; 2016; 2019; Brounce et al. 2014). However, XANES qualitative analyses of hydrous glasses and melt inclusions can be compromised by beam damage

42 (Cottrell et al. 2018). Additionally, it has been shown that $\mathrm{Fe}^{+3} / \Sigma \mathrm{Fe}$ ratio of melts can change on the order of minutes by interaction with atmospheric oxygen (Helz et al. 2017). Due to these 44 challenges and issues, as well as the low preservation potential of pristine volcanic glasses, 
45 alternative methods of determining magmatic $\mathrm{fO}_{2}$, such as $\mathrm{V} / \mathrm{Sc}$ and $\mathrm{Zn} / \mathrm{Fe}$ ratios in bulk rocks

46 (Lee et al. 2005; 2010), as well as the partitioning of V into olivine (Canil, 1997; Mallmann and

47 O'Neill, 2009; 2013; Nicklas et al. 2018; 2019; 2021), have been developed. The oxidation state 48 of vanadium in magmas varies from $\mathrm{V}^{+3}$ to $\mathrm{V}^{+5}$; the former being much more compatible in olivine, regardless of temperature, pressure and melt composition (Canil, 1997; Wang et al. 2019). The most important advantage of Vanadium-in-olivine oxybarometry over XANES Fe oxybarometry,

51 is the possibility to obtain $\mathrm{fO}_{2}$ values of the melt at the first crystallization of primitive olivine, in 52 many cases prior to any magmatic degassing. In contrast, XANES measures the $\mathrm{fO}_{2}$ as glass quenches, after the melt might have been modified by degassing and or assimilation processes.

54 Additionally, $\mathrm{V}$-in-olivine oxybarometry values are relatively hard to reset, as $\mathrm{V}$ diffusion in olivine 55 is fairly slow with a diffusion coefficient on the order of $10^{-14} \mathrm{~m}^{2} / \mathrm{s}$ (Chakraborty, 2010). This method can give erroneous results however, if the measured olivines are xenocrysts and did not

57 crystallize from the rock in which they are found. Vanadium-in-olivine oxybarometry can be 58 readily applied to primitive olivine-phyric lavas from a variety of settings.

In contrast to arc basalts, the $\mathrm{fO}_{2}$ of ocean island basalts (OIB) has only recently received significant attention. It has been postulated, based on XANES measurements in glassy melt

61 inclusions, that Hawaiian basalts are oxidized relative to mid-ocean ridge basalts (MORB), 62 although degassing of sulfur has led to substantial modification of their observed $\mathrm{fO}_{2}$ 63 (Moussallam et al. 2016; Brounce et al. 2017). A similar argument for degassing of sulfide and 64 oxidation has also been demonstrated for intraplate alkaline lavas from Mt Erebus in Antarctica 65 (Moussallam et al. 2014). The high values of $\mathrm{fO}_{2}$ (relative to MORB) measured in spinel grains 66 hosted in residual mantle xenoliths from Cape Verde also suggest an oxidized mantle source for 
67 Cape Verde magmas (Ryabchikov et al. 1995). Basaltic glasses from the Reykjanes Ridge adjacent to Iceland show a positive correlation between oxygen fugacity and proxies for geochemical enrichment, suggesting that significant amounts of oxidized surficial material are present within the Iceland plume (Shorttle et al. 2015; Novella et al. 2020). The idea that OIB source mantle is

71 uniformly oxidized was extended by Moussallam et al. (2019) using new XANES measurements

72 of melt inclusions of Cape Verde and the Canary Islands, along with a compilation of existing data

73 from Mt. Erebus, Hawaii and Iceland. They showed a strong correlation of $\mathrm{Fe}^{+3} / \Sigma \mathrm{Fe}$ ratio with

74 volatile concentrations, especially $\mathrm{S}$, suggesting that undegassed OIB lavas have $\mathrm{fO}_{2}$ of $\sim+2$ log 75 units from the FMQ buffer, substantially higher than MORB, which are close to FMQ (Berry et al. 76 2018). However, this XANES method only gives a minimum $f \mathrm{O}_{2}$, as even the most oxidized glasses

77 may have experienced some sulfur degassing. Vanadium-in-olivine oxybarometry offers an earlier 'snapshot' of the $\mathrm{fO}_{2}$ of such lavas, potentially enabling a better approximation of the oxygen fugacity of OIB mantle. In order to examine the $\mathrm{fO}_{2}$ of $\mathrm{OIB}$, and to determine whether their source is oxidized relative to the MORB source we applied V-in-olivine oxybarometry to a

81 diverse set of OIB lavas from several different hotspots that are considered to contain recycled 82 crustal components. sample OIB localities with $\mathrm{Sr}-\mathrm{Nd}-\mathrm{Pb}-\mathrm{O}$ s isotope signatures attributed to the recycling of oceanic

87 or continental crustal sources and come from the Canary Islands, the Azores, Samoa, and 88 Mangaia in the Cook Islands. Critically, Mangaia lavas show the highest ${ }^{206} \mathrm{~Pb} /{ }^{204} \mathrm{~Pb}$ of any OIB 
and thus represent the HIMU endmember (high- $\mu$ : high long-term ${ }^{238} \mathrm{U} /{ }^{204} \mathrm{~Pb}$ ) (Woodhead, 1996), while Samoan lavas represent the EM2 (Enriched Mantle) isotopic endmember (Jackson et al. 2007a). The Canary Island lavas are 'HIMU-type' (Day et al., 2010), and samples from the same

92 Canary Island volcanos have also been measured by Moussallam et al. (2019) by XANES. The Azores samples span a range of compositions from enriched mantle (EM)-like (eastern São Miguel; Elliot et al. 2007), to akin to MORB-like lavas (Pico; Waters et al., 2020). Background details about the samples are given in the Supplementary Information. Vanadium-in-olivine oxybarometry relies upon the experimentally constrained and the $\mathrm{V}$ concentration of the parental melt of the olivine can be constrained, $\mathrm{fO}_{2}$ can be calculated. Concentrations of trace elements, including $V$, in the cores of primitive olivine crystals were measured using laser ablation inductively coupled plasma mass spectrometry (LA-ICP-MS). The analytical details can be found in the Supplementary Information. Calculation of parental magma compositions used previously published bulk rock data and the method of (Nicklas et al. 2021) and are detailed in the Supplementary Information. In short, literature bulk rock data were used with the major element composition of the analyzed olivine to calculate the $\mathrm{MgO}$ content of the parental magma to the olivine. The method assumes FeO in the bulk rock samples are equal to that in the parental magmas, and this assumption has at most a secondary effect on the resulting $\mathrm{fO}_{2}$ values. The measured composition of the olivine was then subtracted from the bulk rock concentrations until it was in equilibrium with the olivine. This calculation was done for all major elements and for $\mathrm{V}$, to establish the parental magma composition. The partition coefficient was then calculated using the average olivine $\mathrm{V}$ concentration and the modeled parental magma 
$111 \mathrm{~V}$ concentration. Oxygen fugacity was then related to $\mathrm{DV}_{\mathrm{v}}^{\text {olivine/melt }}$ using the empirical calibration 112 of Wang et al. (2019).

\section{Results}

The average concentrations of $\mathrm{V}, \mathrm{Al}, \mathrm{Ca}, \mathrm{Ni}, \mathrm{Co}, \mathrm{Ga}$ and $\mathrm{Y}$ in olivine cores from the studied

116 OIB samples are listed in Table 1. Vanadium concentrations range from $3.8 \pm 0.4$ (2SD) ppm (in

117 GC0901) to $6.3 \pm 0.7 \mathrm{ppm}$ (in MG1006). Ca concentrations in olivine range from 1017 to 2707

118 ppm, firmly establishing that the olivines crystallized from magmas and are not mantle 119 xenocrysts, which are globally characterized by $<700$ ppm Ca (Foley et al. 2013). Calculated 120 parental magma compositions, as well as each parental magma's non-bonding

121 oxygen/tetrahedrally bound oxygen (NBO/T) ratios are listed in Table 2. Parental magma MgO 122 concentrations varied between 8.7 (in PX0802) and 17.4 wt.\% (in AVON3-71-22) and parental 123 magma V concentrations varied between 226 ppm (in PX0802) and 424 ppm (in EH10) while 124 NBO/T ratios varied between 0.84 (in PX0802) and 1.43 (in AVON3-71-22). All parental lavas had $125>8 \mathrm{wt} . \% \mathrm{MgO}$, and therefore in most cases, olivine was the only accumulated phase, whereas for 126 a few samples both olivine and clinopyroxene were accumulated phases. To examine whether 127 clinopyroxene accumulation affected the oxybarometry calculations, we measured the 128 concentration of $\mathrm{V}$ in pyroxene in LP01, EH18 and LZ0601 samples that host large clinopyroxene 129 crystals. We show that even if the bulk rock contained $50 \%$ accumulated pyroxene, the calculated $130 \mathrm{fO}_{2}$ would change by $0.27,0.26,0.69 \mathrm{log}$ units, respectively. Based on petrographic investigations 131 (see Online Supplementary Materials), the maximum modal clinopyroxene content is less than 
$13230 \%$, and therefore pyroxene accumulation had at most a marginal effect on the calculated $\mathrm{fO}_{2}$ values. Information on the modeling of clinopyroxene accumulation can be found in Table 3 . between $+1.52^{+0.36}{ }_{-0.30} \Delta \mathrm{FMQ}\left(\right.$ in SM0815) and $+2.86^{+0.28}{ }_{-0.24} \Delta \mathrm{FMQ}$ (in GC0901). The four Mangaia samples all show $\mathrm{fO}_{2}$ values that overlap within uncertainties of each other, consistent with the

137 close relationships of lavas in the field and suggesting a statistically identical parental magma. 138 Calculated $\mathrm{fO}_{2}$ values for all OIB samples show no correlation with either modeled parental magma MgO content (Figure 1), olivine Mg\# (Supplemental Figure 1) or bulk rock isotopic signatures (Figure 2), despite wide variation in ${ }^{206} \mathrm{~Pb} /{ }^{204} \mathrm{~Pb}$ (from 19.126 to 21.640) and parental magma $\mathrm{Al}_{2} \mathrm{O}_{3}$ and $\mathrm{Na}_{2} \mathrm{O}$ concentrations (Tables 2 and 4), making it unlikely that different 143 partial melting degrees caused the observed variation. A grand average of all the OIB yields a 144 value of $+1.96 \pm 0.70$, significantly more oxidized than the MORB average using the V-in-olivine 145 method at $+0.60 \pm 0.15 \triangle \mathrm{FMQ}$ (Nicklas et al. 2018) and the MORB average using XANES measurements at $-0.18 \pm 0.16 \Delta \mathrm{FMQ}$ (Zhang et al. 2018) or $\sim+0.1 \Delta \mathrm{FMQ}$ (Berry et al. 2018). The

147 OIB average calculated here is also within uncertainties of data for OIB lavas from Kilauea Iki and 148 the Western Rift Zone of Iceland of $+1.64^{+0.19}-0.17$ and $+1.38^{+0.27}-0.23 \Delta \mathrm{FMQ}$, respectively, calculated 149 using an identical procedure and the olivine and whole rock data of Nicklas et al. (2019). If all the 150 data are recalculated using higher olivine crystallization temperatures of either $1250^{\circ} \mathrm{C}$ or $1300^{\circ} \mathrm{C}$ 151 (Table 4), the relative positions of the data are unaffected and the average shifts to $+1.63 \pm 0.70$ 152 and $+1.48 \pm 0.70 \triangle \mathrm{FMQ}$, respectively, still significantly higher than MORB. 


\section{Discussion}

Vandium-in-olivine oxybarometry data from this study, combined with those from Hawaii and Iceland (Nicklas et al., 2019) indicate oxidized mantle sources for all OIB measured to date, consistent with the conclusions from XANES measurements (Moussallam et al., 2019). Critically,

158 these observations show that OIB have elevated $\mathrm{fO}_{2}$ at $+2.0 \pm 0.7$ (2SD) $\triangle \mathrm{FMQ}$ compared to MORB 159 at $+0.6 \pm 0.2(2 \mathrm{SD}) \Delta \mathrm{FMQ}$, measured using the same redox proxy, and also lack any correlation 160 between $\mathrm{fO}_{2}$ and isotopic signatures or with petrological indicators of magmatic differentiation 161 (e.g., parental magma MgO, olivine Mg\#). A subset of the samples from the Canary Islands, 162 Mangaia and Samoa have also been analyzed for O and Si stable isotopic systematics (Day et al. 163 2009; Pringle et al. 2016), but these signatures also show no correlation with $\mathrm{fO}_{2}$, although data 164 are limited. The dichotomy between reduced MORB and oxidized Samoan OIB is also consistent 165 with the relatively high $S^{+6} / \Sigma S(0.17 \pm 0.11)$ of Samoan lavas (Labidi et al. 2015). The lack of 166 correlation of $\mathrm{fO}_{2}$ with isotopic signatures in the OIB dataset contrasts to prior observations made 167 using MORB datasets. For example, the XANES study of Cottrell and Kelley (2013) showed that 168 isotopically enriched MORB have resolvable lower $\mathrm{fO}_{2}$, which they attributed to reduced carbon 169 amount in their source regions. This correlation could also possibly instead reflect isotopically 170 enriched MORB being generally more volatile rich, and thus having degassed more S. Our new 171 average OIB $\mathrm{fO}_{2}$ value overlaps with the range of global arc basalts (i.e., Carmichael, 1991; Kelley 172 and Cottrell, 2009) and also coincides with that of high MgO Siberian meimichites ( $+2.5 \Delta$ FMQ) 173 estimated using V-in-olivine oxybarometry (Mungall et al. 2005). 
Although the data of Moussallam et al. (2019) showed that OIB are indeed oxidized, melt

175 inclusions XANES is perhaps not the best way of constraining OIB source region $\mathrm{fO}_{2}$ for two main 176 reasons. Firstly, degassing has affected the measured $\mathrm{fO}_{2}$ of the samples, and thus only a

177 minimum $\mathrm{fO}_{2}$ can be calculated. It has been argued that some modern Canary lavas are the most

178 S-rich contemporary lavas on Earth and are thus especially susceptible to substantial modification

179 by degassing (Taracsak et al. 2019). Secondly, several of the samples from that study showed high

180 volatile concentrations (up to $\sim 3 \% \mathrm{H}_{2} \mathrm{O}$ ) which can cause significant analytical problems during

181 XANES analysis (Cottrell et al. 2018) and those authors also did not seek to correlate $\mathrm{fO}_{2} \mathrm{with}$

182 isotopic evidence for recycled material in their sample set. The concordance of our average OIB

$183 \mathrm{fO}_{2}$ with the plume $\mathrm{fO}_{2}$ inferred by Moussallam et al. (2019) is remarkable, and more V-in-olivine

184 oxybarometry and XANES measurements of the same samples will serve to clarify the utility of 185 these two oxybarometry methods for OIB studies.

\section{Crustal contamination, degassing and fractional crystallization}

The uniformly high $\mathrm{fO}_{2}$ of OIB strongly suggests that their mantle sources are oxidized

relative to ambient upper mantle sampled by MORB. Oxygen fugacity can be modified, however,

by several post-mantle processes, such as fractional crystallization, crustal contamination, and

192 mineral assemblage preferentially incorporates $\mathrm{Fe}^{+2}$ over $\mathrm{Fe}^{+3}$, as olivine and clinopyroxene do

193 (Cottrell and Kelley, 2011). Modelling has shown that fractional crystallization has a relatively 194 minor effect on melt $\mathrm{fO}_{2}$ until the lava reaches $8 \mathrm{wt} . \% \mathrm{MgO}$ (Kelley and Cottrell, 2012), lower 


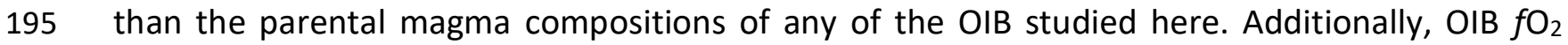
196 shows no correlation with parental magma MgO content (Figure 1), indicating negligible effect 197 of mafic mineral fractionation on $\mathrm{fO}_{2}$. More recent studies of $\mathrm{MORB}$ lavas show that $\mathrm{fO}_{2}$ of lavas 198 can be affected by fractional crystallization (Shorttle et al. 2015) but also found the effect to be 199 minimal, only increasing $\mathrm{Fe}^{+3} / \Sigma \mathrm{Fe}$ by 0.01 per 2.0 wt.\% change in $\mathrm{MgO}$ content. Given the spread 200 in parental magma $\mathrm{MgO}$ content of the OIB dataset, fractional crystallization will not lead to 201 significant increases in $\mathrm{fO}_{2}$. Due to the generally lower $\mathrm{MgO}$ content of MORB lavas (Figure 1) and 202 the fact that crystallization of olivine can only have an oxidizing effect on magma, it is unlikely 203 that the $\mathrm{fO}_{2}$ difference between OIB and MORB is generated by fractional crystallization. The 204 Mangaia samples have radiogenic $\mathrm{Pb}$ isotope ratios, and so are likely to contain the largest $\mathrm{AOC}$ 205 contribution yet show among the lowest $\mathrm{fO}_{2}$ of the OIB samples. The relatively low parental 206 magma $\mathrm{MgO}$ content to the Mangaia samples (10 wt.\%) shows that the reported $\mathrm{fO}_{2}$ would be even lower if fractional crystallization had significantly affected these samples. We can therefore rule out significant effects of fractional crystallization on $\mathrm{fO}_{2}$ for our sample set. oxidized elements such as $\mathrm{Fe}^{+3}$. Due to the relatively low Fe content of the continental crust (and 211 terrigenous sediments) even $\sim 30 \%$ continental crustal assimilation is unlikely to have significantly 212 affected the $\mathrm{fO}_{2}$ of a mantle-derived melt (Grocke et al 2005). The studied OIB suites are all 213 situated on oceanic crust which is relatively Fe-rich, but not grossly more so than the OIB parental 214 lavas themselves, meaning that significant (>20\%) quantities of assimilation would be necessary 215 to modify their $\mathrm{fO}_{2}$. Large amounts of assimilation of oxidized altered oceanic crust from the 216 underlying plate would affect significantly geochemical signatures of the respective OIB (e.g., 
217 Jackson et al., 2007; Day et al., 2010; Waters et al., 2020), leading to correlations with $f \mathrm{O}_{2}$, which

218 are not observed (Fig. 3). In particular, while the available data are limited, no correlation is seen

219 between $\mathrm{O}$ isotopes (Day et al., 2009; 2010) and $\mathrm{fO}_{2}$, further demonstrating that assimilation was

220 a minor process. Finally, although crustal assimilation has been documented in selected Azores

221 lavas using B and Li isotopes (Genske et al. 2014), such signatures do not indicate the $>20 \%$

222 assimilation necessary to change $\mathrm{fO}_{2}$ beyond uncertainties.

It has been shown in the literature that degassing of sulfur in OIB melts can have a strong

224 reducing effect on the $\mathrm{fO}_{2}$ of a melt, with 6 moles of $\mathrm{Fe}^{+3}$ reduced to $\mathrm{Fe}^{+2}$ for every mole of $\mathrm{S}^{-2}$

225 degassed as $\mathrm{SO}_{2}$ (Moussallam et al. 2014; 2016; 2019). Water and $\mathrm{CO}_{2}$ degassing, in contrast,

226 have negligible effects on the $\mathrm{fO}_{2}$ of an evolving melt (Moussallam et al. 2014; Waters et al. 2016).

227 Sulfur degassing is not the cause of the OIB-MORB $\mathrm{fO}_{2}$ dichotomy for three reasons: first and 228 most importantly, as $\mathrm{V}$-in-olivine oxybarometry measures $\mathrm{fO}_{2}$ as olivine is crystallized early in a 229 magma's evolution, it likely avoids much of the degassing that is observed from XANES 230 measurements on glass. Second, $\mathrm{S}$ degassing has only been shown to have a reducing effect and 231 could not oxidize OIB relative to MORB, although it is possible that the global MORB signature is 232 underestimated, as most MORB are sulfide-saturated during eruption (Le Voyer et al. 2015). 233 Third, our new OIB average overlaps well with the estimate for global undegassed OIB measured 234 by XANES (Moussallam et al. 2019), which is unlikely if degassing was the root cause of the 235 oxidized OIB signature. For these reasons, we conclude that the oxidized OIB signature is derived 236 from a relatively oxidized OIB source mantle, consistent with the conclusions of Moussallam et 237 al. (2019) and is not the result of later magmatic processes. 


\section{Lithologically distinct mantle sources?}

It has been postulated that some OIB magmas preferentially sample olivine-free

241 lithologies such as mantle pyroxenites as opposed to normal mantle peridotite (Sobolev et al.

$2422005 ; 2007)$ due to the high Ni content (and to a lesser extent low Mn and Ca) at constant Mg\#

243 in OIB olivine as opposed to MORB olivine. However, elevated Ni signatures have also been

244 attributed to contamination by core metal (Herzberg et al. 2013), or high-pressure melting of 245 normal mantle peridotite (Matzen et al. 2017; Gleeson and Gibson, 2019). To investigate if

246 different mantle lithologies show different $\mathrm{fO}_{2}$, oxygen fugacity is plotted against average olivine

$247 \mathrm{Ni} / \mathrm{MgO}$ in Figure 3. No correlation is observed, indicating that any difference in $\mathrm{fO}_{2}$ between 248 pyroxenite and peridotite in OIB sources is not resolvable in the current dataset. This conclusion 249 only holds, however, if high $\mathrm{Ni}$ in olivine reflects a larger pyroxenite component (Sobolev et al. 250 2005), which is disputed (Matzen et al. 2017; Gleeson and Gibson, 2019). It is therefore not 251 simple to determine if OIB lavas originate from melting of peridotite or pyroxenite. For example, 252 it is also disputed whether the isotopically enriched-endmember in the Canary plume derives 253 from pyroxenite or peridotite (Day et al. 2009, 2012; Gurenko et al. 2009). Pyroxenite is 254 conventionally thought to be the result of hybridization of recycled AOC and peridotite (Sobolev 255 et al. 2005), and therefore would likely be more $\mathrm{Fe}^{+3}$-rich (i.e., high $\mathrm{fO}_{2}$ ) than ambient peridotite. 256 Either pyroxenite in the sources of the studied OIB is not more oxidized than peridotite, or 257 pyroxenite-derived melt represents a minor portion of the parental melts contributing to the 258 studied lavas so as to be undetectable by the method use here. In either scenario, more data are 259 necessary on pyroxenite and peridotite-derived OIB to clarify the issue. It is worth noting that 
260

261

262

263

264

265

266

267

268

269

270

271

272

273

274

275

276

277

278

279

280

previous studies have concluded that pyroxenite is lacking in the source of Azores lavas (Sobolev et al. 2007).

\section{Oxidized sources and crustal recycling processes}

Oxygen fugacity shows no correlation with bulk-rock isotopic signatures for ${ }^{06} \mathrm{~Pb} /{ }^{204} \mathrm{~Pb}$, ${ }^{143} \mathrm{Nd} /{ }^{144} \mathrm{Nd}$ and ${ }^{187} \mathrm{Os} /{ }^{188} \mathrm{Os}$ (Figure 2). This is unexpected, given that the dataset samples a wide range of geochemical compositions, including some of the most extreme HIMU signatures present in mantle-derived lavas, which are likely to host large amounts of AOC in their source regions. The Mangaia HIMU end-member likely hosts a component of subducted $\sim 2.5$ Ga AOC (e.g., Cabral et al., 2013). HIMU is characterized by high ${ }^{206} \mathrm{~Pb} /{ }^{204} \mathrm{~Pb}$, which results from high ${ }^{238} \mathrm{U} /{ }^{204} \mathrm{~Pb}$ in a long-lived mantle source (Chauvel et al. 1992; Woodhead et al. 1996). The mantle source of HIMU lavas is thought to host 5\% AOC mixed with ambient mantle (Nebel et al. 2013).

Whether the AOC is present as a separate, oxidized pyroxenite lithology or the isotopic signatures of $A O C$ have been imparted onto normal peridotite without a separate lithology being present is unsettled (Herzberg et al. 2014).

For the purpose of our modeling, we assume that $\mathrm{AOC}$ isotopic signatures in the Mangaia source are accompanied by oxidized $\mathrm{AOC} F \mathrm{Fe}$. AOC has a relatively high $\mathrm{Fe}^{+3} / \Sigma \mathrm{Fe}$ of $0.22 \pm 0.08$ but can locally reach values as high as 0.36 (Evans, 2012). Even Archean AOC is likely highly oxidized, as oxidation of $A O C$ is largely the result of serpentinization reactions in the presence of water and has little to do with atmospheric $\mathrm{O}_{2}$ content (i.e., Kasting, 2014). Assuming that ambient MORB mantle has 8.05 wt.\% total $\mathrm{FeO}$ (McDonough and Sun, 1995) with a $\mathrm{Fe}+3 / \Sigma \mathrm{Fe}=0.05$ 
281 (Cottrell and Kelley, 2011) and recycled AOC has 10.43 wt.\% total FeO (Gale et al. 2013) with a $282 \mathrm{Fe}^{+3} / \Sigma \mathrm{Fe}=0.22$ to 0.36 (Evans, 2012), a mixture of $95 \%$ ambient mantle and $5 \%$ AOC has a $283 \mathrm{Fe}^{+3} / \Sigma \mathrm{Fe}$ of 0.06 to 0.07 . Assuming temperature is constant and mantle spinel does not change 284 in composition by addition of $\mathrm{AOC}$ except to increase in $\mathrm{Fe}^{+3}$ content, addition of $5 \% \mathrm{AOC}$ is 285 calculated using the method of Ballhaus et al. (1991) to raise the $\mathrm{fO}_{2}$ of the HIMU source by 0.34$2860.58 \log$ units $\triangle \mathrm{FMQ}$. These differences are possibly resolvable using our method, which has 287 uncertainties varying from 0.13 to $0.59 \log$ units $\triangle \mathrm{FMQ}$. compatibilities of lithophile trace element systems and redox-sensitive elements. By far the most 290 abundant redox-sensitive element in mantle and recycled crustal lithologies is Fe (Evans, 2012), 291 which is a major element in both mantle and crust and shows only a moderate degree of 292 incompatibility during melting events. By contrast, parent, daughter or both isotopes in the Rb$293 \mathrm{Sr}, \mathrm{Sm}-\mathrm{Nd}, \mathrm{U}-\mathrm{Pb}, \mathrm{Th}-\mathrm{Pb}$ and Lu-Hf systems, all consist of highly incompatible elements. 294 Abundances of $\mathrm{Sr}, \mathrm{Nd}, \mathrm{Pb}$, and $\mathrm{Hf}$ are all highly enriched in crustal lithologies relative to the 295 depleted mantle (Rudnick and Gao, 2003; Salters and Stracke, 2004), and therefore their budget 296 in OIB lavas may be dominated by a volumetrically minor enriched lithology similar to the model 297 of Stracke et al. (2019). For example, extreme EM2 lavas from Samoa show strong isotopic 298 similarities to continental sediments, but the signature can be explained by mixing only 6\% 299 sediment into their mantle source region (Jackson et al. 2007). Indeed, Samoan lavas studied 300 here show average $\mathrm{fO}_{2}$ that is not resolvable from the global OIB dataset. 
The radiogenic components responsible for HIMU may not mix as a separate lithology with ambient mantle, but instead melt and mix with melts derived from more depleted mantle lithologies. The chalcophile nature of $\mathrm{Pb}$ (Hart and Gaetani, 2006) during mantle melting means that a very small volume of S-rich melt could host radiogenic $\mathrm{Pb}$, dampening such a melt's effect on $\mathrm{fO}_{2}$ and major element abundances. Strong variations in OIB isotopic signatures are generally only present for elements that are highly enriched in crustal lithologies, as demonstrated by the 307 relatively muted variations in major element isotopic signatures in OIB, such as Fe and Si isotopes 308 (Williams et al. 2014; Pringle et al. 2016). Notably, Os is highly compatible during mantle melting, 309 and Os isotope systematics are often decoupled from lithophile isotope systems in OIB as 310 peridotite components will control Os systematics while recycled components control lithophile 311 isotope systematics (Day 2013). Lead isotopic signatures are also decoupled from $\mathrm{Nd}$, Sr, and Hf 312 isotopic systematics, likely because $\mathrm{Pb}$ is controlled by mantle sulfide as opposed to silicate 313 phases (Hart and Gaetani, 2006). The high $\mathrm{fO}_{2}$ component in OIB therefore probably samples a 314 common, volumetrically dominant plume component (i.e., depleted plume or ambient mantle 315 component) relative to the volumetrically minor recycled components that are enriched in 316 incompatible elements that control $\mathrm{Nd}, \mathrm{Sr}, \mathrm{Hf}$ and potentially $\mathrm{Pb}$ isotope systematics. This simple 317 conceptual model leads to the lack of correlation between oxygen fugacity and long-lived 318 radiogenic or stable isotope systematics. 
Although isotopic parameters show no systematic variations with oxygen fugacity

322 between OIB samples, it is evident that the OIB probe more isotopically enriched and diverse 323 mantle signatures and are more oxidized than MORB. The presented dataset can be used to 324 constrain the isotopic composition of this mantle component present in OIB but not MORB. 325 Numerous studies have proposed the existence of a common mantle component present in OIB 326 (e.g., Hart et al. 1992; Farley et al. 1992; Stracke et al. 2005), which has been termed either 327 "FOZO" or "PHEM". This component is thought to be located at the intersection of all major OIB 328 isotopic arrays and to carry a high- ${ }^{3} \mathrm{He} /{ }^{4} \mathrm{He}$ ratio and moderately depleted $\mathrm{Sr}, \mathrm{Nd}$, and $\mathrm{Hf}$ isotopic 329 signatures and unradiogenic $\mathrm{Pb}$. If this component is indeed present in all the studied OIB 330 samples, it may be volumetrically dominant enough to give all the OIB uniformly elevated $f_{2}$.

331 Selected Samoan lavas examined here have been shown to have high ${ }^{3} \mathrm{He} /{ }^{4} \mathrm{He}(\mathrm{Ofu}-04-14$ has $332{ }^{3} \mathrm{He} /{ }^{4} \mathrm{He}$ of $25 \mathrm{Ra}$; Jackson et al. 2007b), but Canary Islands (Day \& Hilton, 2011), and Mangaia 333 lavas have lower ${ }^{3} \mathrm{He} /{ }^{4} \mathrm{He}$, in some cases even lower than MORB lavas (Parai et al., 2009). Azores 334 lavas are largely MORB-like with regard to He isotopes, ranging from 7.2 to $11.1 \mathrm{R}_{\mathrm{a}}$ (Moriera et 335 al. 1999; 2012; Madureira et al. 2014). It is notable that regardless of the wide variation in He 336 isotopic signatures in the studied OIB, there seems to be no variation in their $\mathrm{fO}_{2}$. 
343 primordial reservoir (Class and Goldstein, 2005), its high $\mathrm{fO}_{2}$ may reflect a more oxidized 344 signature for such a reservoir. The DMM likely lost some of its oxidized elements by melting 345 events depleting it in $\mathrm{Fe}^{+3}$ over time while the common component could have remained 346 relatively undepleted. More extensive modeling on the effect of melting on the $\mathrm{fO}_{2}$ of residual 347 mantle lithologies is needed to constrain this model. Alternatively, if the common component is 348 hosted in the lower mantle, and formed early in Earth history, it could be oxidized due to the loss 349 of disproportionated metallic Fe (i.e., metallic Fe formed from the reaction $3 \mathrm{Fe}^{+2} \rightarrow \mathrm{Fe}^{0}+2 \mathrm{Fe}^{+3}$ ) 350 from the lowermost mantle during a primordial magma ocean phase (Wood et al. 2006). If the 351 common component was oxidized shortly after core formation and preserved (unmixed with 352 upper mantle) until the present day, it would present an oxidized signature, similar to the model 353 for the source of the 3.55 Ga Schapenburg komatiites (Nicklas et al. 2019). The Schapenburg 354 komatiites show isotopic evidence for early lower mantle processes as well as very high $\mathrm{fO}_{2}$ 355 compared to other Archean komatiites, making it likely that their mantle source region was 356 oxidized by loss of disproportionated Fe early in Earth history. While it may seem implausible that 357 early-formed mantle reservoirs could still be sampled by modern plume lavas, the high- ${ }^{3} \mathrm{He} /{ }^{4} \mathrm{He}$ 358 signatures of OIB and the recently discovered ${ }^{182} \mathrm{~W} /{ }^{184} \mathrm{~W}$ anomalies in OIB with high- ${ }^{3} \mathrm{He} /{ }^{4} \mathrm{He}$ 359 (Mundl et al., 2017) suggest that primordial mantle signatures continue to be sampled in modern 360 lavas. Regardless of whether the high $\mathrm{fO}_{2}$ of the common OIB component is the result of a 361 uniform recycled source (Stracke et al., 2005) or an early-formed geochemically depleted source 362 (Hart et al., 1992; Mundl-Petermeier et al., 2020), more OIB $\mathrm{fO}_{2}$ data from more plumes, including 363 those with extreme isotopic signatures, are necessary to clarify the issue. Of particular interest is 364 the measurement of $\mathrm{fO}_{2}$ in samples with ${ }^{182} \mathrm{~W} /{ }^{184} \mathrm{~W}$ anomalies, which are sensitive indicators of 
365 the presence of early-formed components in mantle plume sources. The current dataset only

366 includes one such sample, OFU-4-14, that shows a strongly negative $\mu^{182} \mathrm{~W}$ anomaly of $-17.3 \pm$ 3674.5 (Mundl-Petermeier et al. 2020) and ${ }^{3} \mathrm{He} /{ }^{4} \mathrm{He}$ ratio of $25 \mathrm{Ra}$ (Jackson et al. 2007) but close to 368 average OIB $\mathrm{fO}_{2}$ of $+1.78^{+0.25}-0.22 \Delta \mathrm{FMQ}$.

370 sediments are present in the sources of OIB (Hofmann, 1997), possibly leading to their high $\mathrm{fO}_{2}$

371 value. There is a strong theoretical framework to support this idea, as mass-balance calculations

372 in subduction zones (Evans, 2012; Brounce et al. 2019) show that the majority of contemporary

373 subducted oxidants $\left(\mathrm{Fe}^{+3}, \mathrm{~S}^{+8}, \mathrm{C}^{+4}\right)$ are not emitted by arc volcanoes, indicating that they are

374 brought into the deep mantle. Indeed, the global study of Evans (2012) suggested that only 10\%

375 of the total subducted oxidants, and almost none of the subducted $\mathrm{Fe}^{+3}$, is emitted by global arc

376 volcanoes. There is substantial isotopic variation found in OIB (Zindler and Hart, 1984; Hofmann,

377 1997) likely because of varying proportions of recycled AOC, as well as terrigenous and pelagic

378 sediments. These different lithologies are likely to show substantially different oxygen fugacity,

379 with $A O C$ and terrigenous sediment being oxidized relative to the mantle, and pelagic organic-

380 rich sediments being reduced. This study shows that the quantity and type of recycled material

381 does not appear to impact the fO2 of the lava. Prior to this study, no work has attempted to

382 correlate isotopic signatures of OIB with oxygen fugacity. More data will show whether the OIB

383 source mantle is indeed uniformly more oxidized than MORB and whether any variation is shown

384 with isotopic signatures. 


\section{Conclusions}

In order to investigate the putatively high oxygen fugacity of the mantle source regions of plume lavas relative to the depleted MORB mantle, we measured the trace element systematics of primitive olivine phenocrysts from twenty OIB samples from the Azores, Samoa, the Canary Islands and the Cook Islands. The OIB samples show a wide range of isotopic signatures, likely sampling a wide variety of recycled crustal materials. Olivine trace element systematics was used to constrain magmatic $\mathrm{fO}_{2}$ in each sample using the $\mathrm{V}$-in-olivine oxybarometry method. All OIB samples are similar in $f \mathrm{O}_{2}$, ranging from $+1.52^{+0.36}{ }_{-0.30} \Delta \mathrm{FMQ}$ to $+2.86^{+0.28}{ }_{-0.24} \Delta \mathrm{FMQ}$, with an average of $1.96 \pm 0.70 \Delta \mathrm{FMQ}$, significantly more oxidized than the V-in-olivine oxybarometry MORB average of $+0.60 \pm 0.15 \Delta \mathrm{FMQ}$. Additionally, OIB $\mathrm{fO}_{2}$ shows no correlation with whole rock ${ }^{206} \mathrm{~Pb} /{ }^{204} \mathrm{~Pb},{ }^{143} \mathrm{Nd} /{ }^{144} \mathrm{Nd}$ and ${ }^{187} \mathrm{Os} /{ }^{188} \mathrm{Os}$ ratios, or with parental magma MgO or inferred pyroxenite content in their source regions. Given the probable presence of oxidized altered oceanic crust in high ${ }^{206} \mathrm{~Pb} /{ }^{204} \mathrm{~Pb}$ OIB, such a null result is significant. This is likely due to isotopic signatures being dominated by volumetrically small, trace element-enriched components, while $\mathrm{fO}_{2}$ reflects the volumetrically dominant component of the OIB source region.

The large and consistent gap in $\mathrm{fO}_{2}$ between MORB and OIB samples indicates that the volumetrically dominant plume component was oxidized relative to the depleted mantle. Two main mechanisms can explain this: either the net OIB source mantle has uniformly high amounts of recycled oceanic crust, or the OIB source reflects a primitive undegassed oxidized reservoir. Early mantle material could have become oxidized shortly after core formation by the segregation of disproportionated Fe metal formed in the lower mantle and be preserved unmixed in the lower mantle till the present day. The presence of ${ }^{182} \mathrm{~W} /{ }^{184} \mathrm{~W}$ isotope anomalies in modern 
408 OIB lend credence to the idea that plumes may sample early formed mantle reservoirs. The new 409 dataset presented here confirms that the modern mantle is heterogeneous with respect to $\mathrm{fO}_{2}$ 410 and that different mantle reservoirs can be accurately characterized using the $\mathrm{V}$-in-olivine 411 oxybarometry method in the future.

\section{Acknowledgements}

Funding for this project was provided by National Science Foundation EAR Grant

415 \#1918322 “A mixed-up mantle beneath Ocean Islands?” (to JMDD). We are grateful to J. Lyakov 416 for development of the LA-ICP-MS correction program. Comments by Oliver Shorttle and an 417 anonymous reviewer are gratefully acknowledged.

419 Author Contributions:

RWN and JMDD designed the project. RKMH and RWN prepared and performed the

421 analyses, data reduction and calculations. The manuscript was written by RWN and RKMH with 422 editing from JMDD, MGJ, VZ, RA and LNW. Samples were collected by JMDD, VZ and MGJ. JMDD 423 provided funding and technical support for the project. 


\section{Figure Captions}

Figure 1. Calculated $\mathrm{fO}_{2}$ of the OIB samples plotted against $\mathrm{MgO}$ content of parental magmas. MORB $\mathrm{fO}_{2}$ field based on olivine-glass pairs from Nicklas et al. (2019).

Figure 2a. Calculated $\mathrm{fO}_{2}$ of the OIB samples plotted against bulk rock ${ }^{187} \mathrm{Os} /{ }^{188} \mathrm{Os}$ ratios. $\mathbf{b}$. Calculated $\mathrm{fO}_{2}$ of the OIB samples plotted against bulk rock ${ }^{206} \mathrm{~Pb} /{ }^{204} \mathrm{~Pb}$ ratios. c. Calculated $f \mathrm{O}_{2}$ of the OIB samples plotted against bulk rock ${ }^{143} \mathrm{Nd} /{ }^{144} \mathrm{Nd}$ ratios. Sources of isotope data are listed in Table 4. MORB isotopic data are from Workman and Hart (2005) and $\mathrm{MORB} \mathrm{fO}_{2}$ data are from Nicklas et al. (2018). Symbols as in Fig. 1.

Figure 3. Average $\mathrm{Ni} / \mathrm{MgO}$, in ppm/wt. \% of olivine plotted against calculated $\mathrm{fO}_{2}$ for each suite. Symbols as in Fig. 1. 
Table 1: Average concentrations of elements (in ppm) in the cores of primitive olivine crystals from each OIB sample. Data were reduced assuming uniform Si concentrations, which are taken from the literature, and vary the least of all major elements in stochiometric olivine. $N-$ number of olivine grains analyzed for each sample, $\mathrm{SiO}_{2}$ - assumed silica content of the olivine in wt.\%, $2 s$ - two standard deviations of the average concentration. For full dataset including concentrations in each spot analyzed, see online supplemental datasets.

\begin{tabular}{|c|c|c|c|c|c|c|c|c|c|}
\hline Sample & $\mathbf{N}$ & $\mathrm{SiO}_{2}$ & Al & $\mathrm{Ca}$ & V & Co & $\mathbf{N i}$ & Ga & $\mathbf{Y}$ \\
\hline LP03 & 19 & 39.28 & 161.4 & 1677 & 4.88 & 160.3 & 1503 & & \\
\hline $2 s$ & & & 34.5 & 518 & 0.77 & 34.7 & 318 & & \\
\hline EH10 & 20 & 38.91 & 182.7 & 1473 & 5.77 & 212.7 & 1369 & 0.20 & 0.14 \\
\hline $2 s$ & & & 39.7 & 259 & 1.11 & 17.4 & 599 & 0.03 & 0.05 \\
\hline GOM05 & 23 & 39.70 & 238.5 & 1774 & 6.21 & 180.9 & 1669 & 0.19 & 0.13 \\
\hline $2 s$ & & & 76.2 & 265 & 1.16 & 14.0 & 177 & 0.06 & 0.04 \\
\hline LZ0601 & 25 & 38.99 & 232.7 & 1756 & 6.16 & 180.4 & 1653 & 0.19 & 0.13 \\
\hline $2 s$ & & & 84.5 & 283 & 1.26 & 14.0 & 202 & 0.06 & 0.04 \\
\hline GC0901 & 19 & 39.05 & 161.4 & 1871 & 3.80 & 179.5 & 2044 & 0.17 & 0.14 \\
\hline $2 s$ & & & 22.3 & 208 & 0.43 & 11.7 & 192 & 0.04 & 0.04 \\
\hline EH18 & 24 & 38.98 & 160.2 & 1017 & 5.79 & 198.6 & 1539 & 0.19 & 0.14 \\
\hline $2 s$ & & & 40.1 & 280 & 1.03 & 29.2 & 1186 & 0.04 & 0.08 \\
\hline LP01 & 33 & 39.05 & 170.6 & 1712 & 5.27 & 193.1 & 1289 & 0.16 & 0.13 \\
\hline $2 s$ & & & 58.8 & 388 & 1.07 & 20.2 & 165 & 0.05 & 0.05 \\
\hline 9CTEN05 & 20 & 39.63 & 203.2 & 2111 & 4.87 & 187.0 & 1476 & 0.16 & 0.12 \\
\hline $2 s$ & & & 27.1 & 249 & 0.53 & 18.4 & 313 & 0.02 & 0.03 \\
\hline 04PAL05 & 20 & 39.39 & 201.6 & 2157 & 4.03 & 157.1 & 1785 & 0.14 & 0.11 \\
\hline $2 s$ & & & 47.9 & 273 & 0.44 & 11.6 & 163 & 0.03 & 0.02 \\
\hline MG01 & 24 & 39.29 & 204.3 & 2575 & 5.63 & 187.1 & 1481 & 0.15 & 0.14 \\
\hline $2 s$ & & & 20.3 & 204 & 0.60 & 10.1 & 66 & 0.03 & 0.02 \\
\hline MG02 & 23 & 38.79 & 202.4 & 2707 & 5.26 & 187.5 & 1523 & 0.11 & 0.15 \\
\hline $2 s$ & & & 16.5 & 242 & 0.47 & 13.7 & 107 & 0.14 & 0.03 \\
\hline MG06 & 23 & 39.36 & 216.8 & 2340 & 6.34 & 225.1 & 1207 & 0.13 & 0.18 \\
\hline $2 s$ & & & 42.7 & 363 & 0.65 & 13.1 & 176 & 0.16 & 0.02 \\
\hline MG08 & 23 & 39.15 & 215.7 & 2115 & 6.28 & 206.1 & 1203 & 0.12 & 0.15 \\
\hline $2 s$ & & & 23.2 & 312 & 0.91 & 19.1 & 300 & 0.18 & 0.03 \\
\hline SM0815 & 19 & 39.75 & 267.4 & 1968 & 5.42 & 179.2 & 1334 & 0.18 & 0.12 \\
\hline $2 s$ & & & 90.4 & 508 & 0.89 & 34.4 & 611 & 0.03 & 0.03 \\
\hline PX0802 & 25 & 39.14 & 192.7 & 1389 & 5.51 & 161.9 & 1307 & 0.17 & 0.14 \\
\hline $2 s$ & & & 40.7 & 374 & 0.79 & 17.1 & 348 & 0.04 & 0.07 \\
\hline TR0802 & 26 & 39.21 & 311.8 & 1805 & 5.09 & 137.2 & 1949 & 0.20 & 0.11 \\
\hline $2 s$ & & & 174.0 & 422 & 1.31 & 38.0 & 1146 & 0.11 & 0.05 \\
\hline T-25 & 19 & 39.54 & 199.3 & 2061 & 5.59 & 161.1 & 2079 & 0.15 & 0.12 \\
\hline $2 s$ & & & 30.9 & 430 & 0.80 & 26.8 & 287 & 0.11 & 0.07 \\
\hline OFU04-14 & 20 & 39.61 & 184.5 & 1882 & 5.74 & 185.2 & 1681 & 0.18 & 0.11 \\
\hline
\end{tabular}




\begin{tabular}{|l|c|c|c|c|c|c|c|c|c|} 
2s & & & 26.7 & 469 & 0.55 & 33.3 & 125 & 0.03 & 0.04 \\
\hline $\begin{array}{l}\text { AVON2-62- } \\
\mathbf{2}\end{array}$ & 20 & 40.34 & 314.2 & 2187 & 4.95 & 159.1 & 2340 & 0.19 & 0.12 \\
\hline $\mathbf{2 s}$ & & & 133.1 & 943 & 1.16 & 30.5 & 653 & 0.05 & 0.04 \\
\hline $\begin{array}{l}\text { AVON3-71- } \\
\mathbf{2}\end{array}$ & 20 & 40.38 & 208.0 & 2273 & 5.00 & 156.8 & 1923 & 0.14 & 0.11 \\
\hline $\mathbf{2 s}$ & & & 75.5 & 460 & 0.99 & 15.0 & 493 & 0.05 & 0.03 \\
\hline
\end{tabular}

Table 2: Calculated major element compositions in weight $\%$, and $V$ concentration in ppm of parental magmas of the studied OIB samples. NBO/T is the ratio of non-bonding oxygens to tetrahedrally bonded oxygens in the parental magmas, calculated using the procedure of Mills (1993).

\begin{tabular}{|c|c|c|c|c|c|c|c|c|c|c|c|c|}
\hline Sample & $\mathrm{SiO2}$ & TiO2 & Al203 & $\mathrm{FeO}$ & MnO & MgO & $\mathrm{CaO}$ & $\mathrm{Na} 2 \mathrm{O}$ & $\mathrm{K} 2 \mathrm{O}$ & P2O5 & $\begin{array}{c}V \\
\text { (ppm) }\end{array}$ & NBO/T \\
\hline LP03 & 51.3 & 2.90 & 11.2 & 13.0 & 0.22 & 12.0 & 8.34 & 0.50 & 0.11 & 0.39 & 266 & 0.95 \\
\hline EH10 & 41.2 & 5.92 & 10.6 & 16.0 & 0.21 & 10.7 & 11.3 & 2.52 & 0.85 & 0.76 & 424 & 1.31 \\
\hline GOM05 & 46.0 & 3.21 & 11.0 & 12.5 & 0.19 & 13.3 & 9.27 & 2.94 & 0.84 & 0.69 & 296 & 1.20 \\
\hline LZ0601 & 47.0 & 2.68 & 13.3 & 13.0 & 0.17 & 9.48 & 11.2 & 1.86 & 0.90 & 0.42 & 292 & 0.97 \\
\hline GC0901 & 44.4 & 4.83 & 13.0 & 12.0 & 0.18 & 9.14 & 12.2 & 2.80 & 1.00 & 0.44 & 354 & 1.02 \\
\hline EH18 & 43.5 & 5.59 & 11.7 & 13.8 & 0.21 & 9.85 & 10.4 & 3.28 & 1.02 & 0.67 & 368 & 1.11 \\
\hline LP01 & 46.1 & 3.59 & 11.6 & 12.3 & 0.20 & 9.86 & 12.8 & 2.33 & 0.87 & 0.44 & 368 & 1.11 \\
\hline 9CTEN05 & 45.5 & 2.59 & 10.6 & 12.1 & 0.17 & 13.14 & 12.9 & 2.03 & 0.62 & 0.31 & 282 & 1.32 \\
\hline 04PAL05 & 42.8 & 3.40 & 11.6 & 12.9 & 0.18 & 11.69 & 13.5 & 2.47 & 0.84 & 0.63 & 402 & 1.30 \\
\hline Mangaia & 44.9 & 2.83 & 11.7 & 12.9 & 0.19 & 10.0 & 14.3 & 2.20 & 0.62 & 0.39 & 311 & 1.20 \\
\hline SM0815 & 47.5 & 3.00 & 12.2 & 10.7 & 0.16 & 12.6 & 8.94 & 2.62 & 1.96 & 0.43 & 243 & 1.06 \\
\hline PX0802 & 48.7 & 2.52 & 14.2 & 9.91 & 0.17 & 8.66 & 10.5 & 3.48 & 1.30 & 0.48 & 226 & 0.84 \\
\hline TR0802 & 47.9 & 2.70 & 14.1 & 10.0 & 0.16 & 9.00 & 12.21 & 2.65 & 0.90 & 0.51 & 262 & 0.89 \\
\hline T-25 & 46.8 & 3.06 & 10.5 & 12.9 & 0.19 & 13.2 & 10.3 & 2.00 & 0.79 & 0.35 & 339 & 1.23 \\
\hline OFU04-14 & 46.0 & 3.89 & 8.88 & 13.2 & 0.17 & 13.1 & 12.3 & 1.53 & 0.62 & 0.35 & 339 & 1.36 \\
\hline AVON2-62-2 & 48.2 & 1.99 & 9.02 & 10.3 & 0.17 & 17.3 & 10.5 & 1.58 & 0.70 & 0.22 & 262 & 1.40 \\
\hline $\begin{array}{c}\text { AVON3-71- } \\
22\end{array}$ & 47.5 & 1.90 & 9.22 & 10.0 & 0.18 & 17.4 & 11.1 & 1.58 & 0.73 & 0.22 & 270 & 1.43 \\
\hline
\end{tabular}


Table 3: Average clinopyroxene $V$ concentrations as determined by a LA-ICP-MS procedure identical to the one for olivine. Bulk rock $\mathrm{V}$ concentrations used to determine $\mathrm{fO}_{2}$ is also listed, along with a bulk $V$ concentration from which $5 \%, 10 \%, 20 \%, 40 \%$ and $50 \%$ of the measured clinopyroxene removed. Finally, the calculated $\mathrm{fO}_{2}$ for each sample is listed, along with an $\mathrm{fO}_{2}$ calculated using the bulk rock compositions with varying amounts of clinopyroxene removed. As demonstrated by the modeling shown here, clinopyroxene accumulation has a negligible effect on the calculated $\mathrm{fO}_{2}$ unless extremely large amount of clinopyroxene was accumulated in the bulk rock samples. $C P X$ - clinopyroxene, $2 s$ - two standard deviations, $N$ - number of clinopyroxenes analyzed.

\begin{tabular}{|c|c|c|c|}
\hline Sample & LP01 & EH18 & LZ0601 \\
\hline CPX V (ppm) & 270 & 294 & 326 \\
\hline 2s & 40 & 55 & 101 \\
\hline $\mathbf{N}$ & 9 & 12 & 10 \\
\hline Bulk V (ppm) & 328 & 357 & 242 \\
\hline Without 5\% CPX & 331 & 360 & 238 \\
\hline Without 10\% CPX & 335 & 364 & 233 \\
\hline Without 20\% CPX & 343 & 372 & 221 \\
\hline Without 30\% CPX & 353 & 383 & 206 \\
\hline Without 40\% CPX & 367 & 398 & 186 \\
\hline Without 50\% CPX & 386 & 419 & 158 \\
\hline fO2 ( $\mathbf{5 P Q})$ & 2.30 & 2.14 & 1.77 \\
\hline Without 5\% CPX & 2.31 & 2.15 & 1.73 \\
\hline Without 10\% CPX & 2.33 & 2.17 & 1.69 \\
\hline Without 20\% CPX & 2.37 & 2.21 & 1.61 \\
\hline Without 30\% CPX & 2.42 & 2.26 & 1.49 \\
\hline Without 40\% CPX & 2.49 & 2.32 & 1.31 \\
\hline Without 50\% CPX & 2.57 & 2.41 & 1.04 \\
\hline
\end{tabular}


Table 4: Calculated parental magma $\mathrm{fO}_{2}$, in log units relative to the $\mathrm{FMQ}$ buffer, as well as bulk rock isotope ratios for the studied OIB samples. The preferred values at $1150^{\circ} \mathrm{C}$ for oxygen fugacity are listed under "FMQ" but also listed are oxygen fugacity values calculated using different olivine crystallization temperatures of $1250^{\circ} \mathrm{C}$ and $1300^{\circ}$ demonstrating the lack of a strong temperature effect on the results. Up - positive uncertainty on the calculated $\mathrm{fO}_{2}$, down - negative uncertainty on the calculated $f_{2}$. $2 \mathrm{~s}$ - quoted 2 sigma uncertainties on the isotope ratios. Sources of isotope data: Jackson et al. (2007a); Day et al. (2010); Jackson et al. (2014); Waters et al. (2020); Day et al. (under review) and Day (unpublished data).

\begin{tabular}{|c|c|c|c|c|c|c|c|c|c|c|c|c|c|}
\hline Sample & Location & MgO & FMQ & Up & Down & ${ }^{206} \mathrm{~Pb} /{ }^{204} \mathrm{~Pb}$ & $2 s$ & ${ }^{143} \mathrm{Nd} /{ }^{144} \mathrm{Nd}$ & $2 s$ & ${ }^{187} \mathrm{Os} /{ }^{188} \mathrm{Os}$ & $2 s$ & $\begin{array}{c}\text { FMQ at } \\
1250 \mathrm{C}\end{array}$ & $\begin{array}{c}\text { FMQ at } \\
1300 \mathrm{C}\end{array}$ \\
\hline LP03 & La Palma & 12.01 & 2.02 & 0.35 & 0.29 & 19.698 & 0.007 & 0.512966 & 0.000017 & 0.14406 & 0.00001 & 1.69 & 1.54 \\
\hline EH10 & El Hierro & 10.69 & 2.20 & 0.41 & 0.33 & 19.597 & 0.007 & 0.512942 & 0.000003 & 0.14808 & 0.00005 & 1.87 & 1.72 \\
\hline GOM05 & $\begin{array}{c}\text { La } \\
\text { Gomera }\end{array}$ & 13.32 & 1.93 & 0.27 & 0.23 & - & - & - & - & - & - & 1.59 & 1.44 \\
\hline LZ0601 & Lanzarote & 9.48 & 1.77 & 0.43 & 0.34 & - & - & - & - & - & - & 1.44 & 1.29 \\
\hline GC0901 & $\begin{array}{c}\text { Gran } \\
\text { Canaria } \\
\end{array}$ & 9.14 & 2.86 & 0.28 & 0.24 & - & - & - & - & - & - & 2.53 & 2.38 \\
\hline EH18 & El Hierro & 9.85 & 2.14 & 0.38 & 0.31 & 19.666 & 0.001 & 0.512952 & 0.000005 & 0.15297 & 0.00006 & 1.80 & 1.65 \\
\hline LP01 & La Palma & 9.86 & 2.30 & 0.43 & 0.34 & 19.759 & 0.001 & 0.512914 & 0.000004 & 0.14328 & 0.00001 & 1.96 & 1.81 \\
\hline 9CTEN05 & Tenerife & 13.14 & 1.79 & 0.27 & 0.23 & - & - & - & - & - & - & 1.45 & 1.30 \\
\hline 04PAL05 & La Palma & 11.69 & 2.71 & 0.27 & 0.23 & - & - & - & - & - & - & 2.38 & 2.23 \\
\hline MG01 & Mangaia & 10.03 & 1.74 & 0.19 & 0.17 & 21.601 & 0.002 & 0.512919 & 0.000005 & 0.14982 & 0.00008 & 1.41 & 1.26 \\
\hline MG02 & Mangaia & 10.03 & 1.78 & 0.16 & 0.15 & 21.600 & 0.002 & 0.512914 & 0.000006 & 0.16064 & 0.00009 & 1.45 & 1.30 \\
\hline MG08 & Mangaia & 10.03 & 1.78 & 0.26 & 0.23 & 21.630 & 0.002 & 0.512904 & 0.000008 & 0.15243 & 0.00006 & 1.45 & 1.30 \\
\hline SM0815 & $\begin{array}{c}\text { Sao } \\
\text { Miguel }\end{array}$ & 12.55 & 1.52 & 0.36 & 0.30 & 19.889 & 0.0002 & 0.512736 & 0.000003 & - & - & 1.19 & 1.04 \\
\hline PX0802 & Pico & 8.66 & 1.65 & 0.32 & 0.27 & 19.804 & 0.0003 & 0.512884 & 0.000003 & 0.12460 & 0.00130 & 1.32 & 1.17 \\
\hline TR0802 & Terceira & 9.00 & 1.99 & 0.54 & 0.41 & 19.311 & 0.0003 & 0.512938 & 0.000003 & 0.13840 & 0.00272 & 1.66 & 1.51 \\
\hline T-25 & Ta'u & 13.17 & 1.95 & 0.32 & 0.27 & 19.2266 & 0.0007 & 0.512790 & 0.000040 & 0.12334 & 0.00009 & 1.62 & 1.47 \\
\hline $\begin{array}{c}\text { OFU04- } \\
14 \\
\end{array}$ & Ofu & 13.12 & 1.78 & 0.25 & 0.22 & 19.1260 & 0.00003 & 0.512819 & 0.000025 & 0.12947 & 0.00008 & 1.45 & 1.30 \\
\hline $\begin{array}{c}\text { AVON2- } \\
62-2\end{array}$ & Vailulu'u & 17.44 & 1.56 & 0.49 & 0.38 & - & - & - & - & 0.12826 & 0.00004 & 1.23 & 1.08 \\
\hline $\begin{array}{c}\text { AVON3- } \\
71-22 \\
\end{array}$ & Vailulu'u & 17.31 & 2.03 & 0.42 & 0.34 & 19.358 & 0.0002 & 0.512747 & 0.000040 & 0.12762 & 0.00007 & 1.70 & 1.55 \\
\hline
\end{tabular}




\section{Works Cited:}

Ballhaus, C., Berry, R. F., Green, D. H. (1991). High pressure experimental calibration of the olivine-orthopyroxene-spinel oxygen geobarometer: implications for the oxidation state of the upper mantle. Contrib. Mineral. Petrol. 107: 27-40.

Berry A. J., Stewart G. A., O’Neill H. St. C., Mallmann G., Mosselmans J. F. W. (2018) A reassessment of the oxidation state of iron in MORB glasses. Earth and Planetary Science Letters 483: 114-123.

Brounce, M. N., Cottrell, E., Kelley, K. A. (2019). The Redox Budget of the Marianas Subduction Zone. Earth and Planetary Science Letters 528: 115859.

Brounce M. N., Stolper E., Eiler, J. (2017) Redox variations in Mauna Kea lavas, the oxygen fugacity of the Hawaiian plume, and the role of volcanic gases in Earth's oxygenation. Proc. Natl. Acad. Sci. 114, 8997-9002.

Brounce M. N., Kelley K. A., Cottrell E. (2014) Variations in $\mathrm{Fe}^{+3} / \Sigma \mathrm{Fe}$ of Mariana Arc Basalts and Mantle Wedge $\mathrm{fO}_{2}$. J. Petrol. 55, 2513-2536.

Cabral, R. A., Jackson, M. G., Rose-Koga, E. F., Koga, K. T., Whitehouse, M. J., Antonelli, M. A., Farquhar, J., Day, J. M. D., Hauri, E. H. (2013) Anomalous sulphur isotopes in plume lavas reveal deep mantle storage of Archaean crust. Nature 496: 490-493.

Canil D. (1997) Vanadium partitioning and the oxidation state of Archaean komatiite magmas. Nature 389, 842-845.

Carmichael I. S. (1991) The redox states of basic and silicic magmas: A reflection of their source regions? Contrib. Mineral. Petrol. 106, 129-141.

Chakraborty, S. (2010) Diffusion coefficients in Olivine, Wadleysite and Ringwoodite. Reviews in Mineralogy and Geochemistry 72: 603-639.

Chauvel C., Hofmann A. W., Vidal P. (1992) HIMU-EM: The French Polynesian connection. Earth and Planetary Science Letters 110: 99-119.

Class C., Goldstein S. L. (2005) Evolution of helium isotopes in the Earth's mantle. Nature 436: 1107-1112.

Cottrell E., Lanzirotti A., Mysen B., Birner S., Kelley K. A., Botcharnikov R., Davis F. A., Newville M. (2018) A Mössbauer-based XANES calibration for hydrous basalt glasses reveals radiation-induced oxidation of Fe. American Mineralogist 103: 489-501.

Cottrell E., Kelley K. A. (2013) Redox Heterogeneity in Mid-Ocean Ridge Basalts as a Function of Mantle Source. Science 340(6138): 1314-1317. 
Cottrell E. Kelley K. A. (2011) The oxidation state of Fe in MORB glasses and the oxygen fugacity of the upper mantle. Earth Planet. Sci. Lett. 305, 270-282.

Day J. M. D., Walker R. J., Watanbe S., Hanski E., Jackson M. G., Widom E. (2020) Osmium-186 anomalies in ocean island basalts from early Earth differentiation. Science Advances (under review)

Day J. M. D. (2013) Hotspot volcanism and highly siderophile elements. Chemical Geology 341: 50-74.

Day J. M. D., Hilton D. R. (2011) Origin of ${ }^{3} \mathrm{He} /{ }^{4} \mathrm{He}$ ratios in HIMU-type basalts constrained from Canary Island lavas. Earth and Planetary Science Letters 305: 226-234.

Day J. M. D., Pearson D. G., Macpherson C. G., Lowry D., Carracedo J.-C. (2010) Evidence for distinct proportions of subducted oceanic crust and lithosphere in HIMU-type mantle beneath El Hierro and La Palma, Canary Islands. Geochimica et Cosmochimica Acta 74: 6565-6589.

Day J. M. D., Pearson D. G., Macpherson C. G., Lowry D., Carracedo J.-C. (2009) Pyroxenite-rich mantle formed by recycled oceanic lithosphere: Oxygen-osmium isotope evidence from Canary Island lavas. Geology 37(6): 555-558.

Evans K. A. (2012) The redox budget of subduction zones. Earth-Sci. Rev. 113, 11-32.

Farley K. A., Natland J. H., Craig H. (1992) Binary mixing of enriched and undegassed (primitive?) mantle components ( $\mathrm{He}, \mathrm{Sr}, \mathrm{Nd}, \mathrm{Pb})$ in Samoan lavas. Earth and Planetary Science Letters 111: 183-199.

Foley S. F., Prelevic D., Rehfeldt T., Jacob D. E. (2013) Minor and trace elements in olivine as probes into early igneous and mantle melting processes. Earth and Planetary Letters 363: 181-191.

Gale A., Dalton C. A., Langmuir C. H., Su Y., Schilling J.-G. (2013) The mean composition of ocean ridge basalts. Geochemistry, Geophysics, Geosystems 14(3): 489-518.

Genske F. S., Turner S. P., Beier C., Chu M.-F., Tonarini S., Pearson N. J., Haase K. M. (2014) Lithium and boron isotope systematics in lavas from the Azores islands reveal crustal assimilation. Chemical Geology 373: 27-36.

Gleeson M. L. M., Gibson S. A. (2019) Crustal controls on apparent mantle pyroxenite signals in ocean-island basalts. Geology 47(4): 321-324.

Grocke S. B., Cottrell E., Silva S. D. and Kelley K. A. (2016) The role of crustal and eruptive processes versus source variations in controlling the oxidation state of iron in Central Andean magmas. Earth Planet. Sci. Lett. 440, 92-104. 
Gurenko A. A., Sobolev A. V., Hoernle K. A., Hauff F., Schmincke H.-U. (2009) Enriched, HIMUtype peridotite and depleted recycled pyroxenite in the Canary plume: A mixed-up mantle. Earth and Planetary Science Letters 277: 514-524.

Hart, S. R., Gaetani, G. A. (2006). Mantle Pb paradoxes: the sulfide solution. Contrib. Mineral. Petrol. 152: 295-308.

Hart, S. R., Hauri, E. H., Oschmann, L. A., Whitehead, J. A. (1992). Mantle Plumes and Entrainment: Isotopic Evidence. Science 256: 517-520.

Helz R. T., Cottrell E., Brounce M. N., Kelley K. A. (2017). Olivine-melt relationships and syneruptive redox variations in the 1959 eruption of Kilauea Volcano as revealed by XANES. Journal of Volcanology and Geothermal Research 333-334: 1-14.

Herzberg C., Cabral C. A., Jackson M. G., Vidito C., Day J. M. D., Hauri E. H. (2014). Phantom Archean crust in Mangaia Hotspot Lavas and the meaning of heterogeneous mantle. Earth and Planetary Science Letters 396: 97-106.

Herzberg C., Asimow P. D., Ionov D. A., Vidito C., Jackson M. G., Geist D. (2013). Nickel and helium evidence for melt above the core-mantle boundary. Nature 493: 393-397.

Hofmann A. W. (1997). Mantle geochemistry: the message from oceanic volcanism. Nature 385: 219-229.

Jackson, M.G. Hart S. R., Konter, J. G., Kurz, M. D., Blusztajn, J., Farley, K. A. (2014). Helium and lead isotopes reveal the geochemical geometry of the Samoan plume. Nature 514: 355358.

Jackson M. G., Hart S. R., Koppers A. A. P., Staudigel H., Konter J., Blusztajn J., Kurz M., Russell J. A. (2007) The return of subducted continental crust in Samoan lavas. Nature 448: 684687.

Kasting J. (2014) Mantle Cooling, Seafloor Serpentinization, and the Rise of Atmospheric $\mathrm{O}_{2}$. American Geophysical Union Fall Meeting, Abstract \#P11C-3782.

Kelley K. A. and Cottrell E. (2012) The influence of magmatic differentiation on the oxidation state of Fe in a basaltic arc magma. Earth Planet. Sci. Lett. 329-330, 109-121.

Kelley K. A. and Cottrell E. (2009) Water and the Oxidation State of Subduction Zone Magmas. Science 325: 605-607.

Kress V. C. and Carmichael I. S. E. (1991) The compressibility of silicate liquidus containing $\mathrm{Fe}_{2} \mathrm{O}_{3}$ and the effect of composition, temperature, oxygen fugacity and pressure on their redox states. Contrib. Mineral. Petrol. 103, 82-92. 
Labidi J., Cartigny, P. Jackson M. G. (2015). Multiple sulfur isotope composition of oxidized Samoan melts and the implications of a sulfur isotope 'mantle array' in chemical geodynamics. Earth and Planetary Science Letters 417: 28-39.

Lee C.-T. A., Luffi P., Le Roux V., Dasgupta R., Albarede F., Leeman W. P. (2010) The redox state of arc mantle using Zn/Fe systematics. Nature 468: 681-685.

Lee C.-T. A., Leeman W. P., Canil D., and Li Z.-X. A. (2005) Similar V/Sc Systematics in MORB and Arc Basalts: Implications for the Oxygen Fugacities of their Mantle Source Regions. Journal of Petrology 46(11): 2313-2336.

Le Voyer M., Cottrell E., Kelley K. A., Brounce M. and Hauri E. H. (2015) The effect of primary versus secondary processes on the volatile content of MORB glasses: An example from the equatorial Mid-Atlantic Ridge ( $\left.5^{\circ} \mathrm{N}-3^{\circ} \mathrm{S}\right)$. J. Geophys. Res. 120, 125-144.

Lindsley D. H. (Ed.). 1991. Oxygen Barometry of Spinel Peridotites. In B.R. Frost (Author), Reviews in Mineralogy and Geochemistry (Vol. 25, 417-432). Mineralogical Society of America.

Madureira, P., Moreira, M., Mata, J., Nunes, J.C., Gautheron, C., Lourenço, N., Carvalho, R., de Abreu, M.P. (2014). Helium isotope systematics in the vicinity of the Azores triple junction: Constraints on the Azores geodynamics. Chemical Geology 372: 62-71.

Matzen A. K., Wood B. J., Baker M. B., Stolper E. M. (2017). The roles of pyroxenite and peridotite in the mantle sources of oceanic basalts. Nature Geoscience 10: 530-535.

McDonough W. F., Sun S.-S. (1995) The composition of the Earth. Chemical Geology 120: 223253.

Moreira M., Kanzari A., Madureira P. (2012). Helium and neon isotopes in São Miguel island

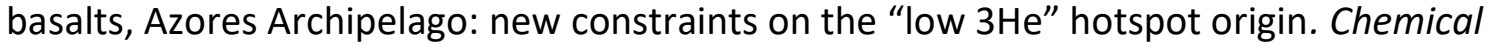
Geology 322: 91-98.

Moreira, M., Doucelance, R., Dupré, B., Kurz, M., Allègre, C.J. (1999). Helium and lead isotope geochemistry in the Azores archipelago. Earth and Planetary Science Letters 169, 189205.

Moussallam Y. et al. (2019) Mantle Plumes are oxidized. Earth and Planetary Science Letters 527, 115798.

Moussallam Y., Edmonds M., Scaillet B., Peters N., Gennaro E., Sides I. and Oppenheimer C. (2016) The impact of degassing on the oxidation state of basaltic magmas: A case study of Kïlauea volcano. Earth Planet. Sci. Lett. 450, 317-325.

Moussallam Y., Oppenheimer C., Scaillet B., Gaillard F., Kyle P., Peters N., Hartley M., Berlo K. and Donovan A. (2014) Tracking the changing oxidation state of Erebus magmas, from 
mantle to surface, driven by magma ascent and degassing. Earth Planet. Sci. Lett. 393, 200-209.

Mundl A., Touboul M., Jackson M. G., Day J. M. D., Kurz M. D., Lekic V., Helz R. T., Walker R. J. (2017). Tungsten-182 heterogeneity in modern ocean island basalts. Science 356: 66-69.

Mundl-Petermeier A., Walker, R. J., Fischer, R. A., Lekic, V., Jackson, M. G., Kurz, M. D. (2020). Anomalous $182 \mathrm{~W}$ in high $3 \mathrm{He} / 4 \mathrm{He}$ ocean island basalts: Fingerprints of Earth's core? Geochimica et Cosmochimica Acta 271: 194-211.

Mungall J. E., Hanley J. J., Arndt N. T., Debecdelievre A. (2006). Evidence from meimechites and other low-degree mantle melts for redox controls on mantle-crust fractionation of platinum-group elements. PNAS 103(34): 12695-12700.

Nicklas R. W., Day J. M. D., Vaci Z., Udry A., Liu Y., Tait K. T. (2021). Uniform Ambient Mantle Oxygen Fugacity and a Highly Oxidized Lithospheric Mantle on Mars. Earth and Planetary Science Letters 564: 116876.

Nicklas R. W., Puchtel I. S., Ash R. D., Piccoli P. M., Hanski E., Nisbet E. G., Waterton P, M., Pearson D. G., Anbar A. D. (2019) Secular Mantle Oxidation across the Archean-Proterozoic Boundary: Evidence from $V$ Partitioning in Komatiites and Picrites. Geochimica et Cosmochimica Acta 250: 49-75.

Nicklas R. W., Puchtel I. S., Ash R. D. (2018). Redox state of the Archean mantle: Evidence from V partitioning in 3.5-2.4 Ga komatiites. Geochim. Cosmochim. Acta 222, 447-466.

Novella D., Maclennan J., Shorttle O., Prytulak J., Murton B. J. (2020). A multi-proxy investigation of mantle oxygen fugacity along the Reykjanes Ridge. Earth and Planetary Science Letters 531: 115973.

Padron-Navarta J. A., Sanchez-Vizcaino V. L., Garrido C. J., Gomez-Pugnaire M. T. (2011) Metamorphic record of high-pressure dehydration of antigorite serpentinite to chlorite harzburgite in a subduction setting (Cerro del Almirez, Nevado-Filabride Complex, Southern Spain). J. Petrol. 52, 2047-2078.

Parai R., Mukhopadhyay S., Lassiter J. C. (2009). New constraints on the HIMU mantle from neon and helium compositions of basalts from the Cook-Austral Islands. Earth and Planetary Science Letters 277: 253-261.

Pringle E. A., Moynier F., Savage P. S., Jackson M. G., Moreira M., Day J. M. D. (2016). Silicon isotopes reveal recycled altered oceanic crust in the mantle sources of Ocean Island Basalts. Geochimica et Cosmochimica Acta 189: 282-295.

Rudnick R. L., Gao S. (2003). The composition of the continental crust, in The Crust, vol. 3, edited by R. L. Rudnick, p. 1-64, Elsevier Sci., New York. 
Ryabchikov I. D., Ntaflos T., Kurat G., Kogarko L. N. (1995). Glass-bearing xenoliths from Cape Verde: evidence for a hot rising mantle jet. Mineralogy and Petrology 55: 217-237.

Salters V. J. M., Stracke A. (2004). Composition of the depleted mantle. Geochemistry, Geophysics, Geosystems 5(5).

Shorttle O., Moussallam Y., Hartley M. E., Maclennan J., Edmonds M., Murton B. J. (2015). FeXANES analyses of Reykjanes Ridge basalts: Implications for oceanic crust's role in the solid Earth oxygen cycle. Earth and Planetary Science Letters 427: 272-285.

Sobolev A. V., Hofmann A. W., Kuzmin D. V., Yaxley G. M., Arndt N. T., Chung S.-L., Danyushevsky L. V., Elliott T., Frey F. A., Garcia M. O., Gurenko A. A., Kamenetsky V. S., Kerr A. C., Krivolutskaya N. A., Matvienkov V. V., Nikogosian I. K., Rocholl A., Sigurdsson I. A., Sushchevskaya N. M., Teklay M. (2007). The Amount of Recycled Crust in Sources of Mantle-Derived Melts. Science 316: 412-417.

Sobolev A. V., Hofmann A. W., Sobolev S. V., Nikogosian I. K. (2005) An olivine-free mantle source of Hawaiian shield basalts. Nature 434: 590-597.

Stracke A., Genske F., Berndt J., Koorneef J. (2019) Ubiquitous ultra-depleted domains in Earth's mantle. Nature Geoscience 12: 851-855.

Stracke A., Hofmann, A. W., Hart, S. R. (2005) FOZO, HIMU, and the rest of the mantle zoo. Geochemistry, Geophysics, Geosystems 6(5).

Tang M., Erdman M., Eldridge G., Lee C.-T. A. (2018) The redox "filter" beneath magmatic orogens and the formation of continental crust. Scientific Advances 4(5): 1-7.

Taracsak Z., Hartley M. E., Burgess R., Edmonds M., Iddon F., Longpre M.-A. (2019). High fluxes of deep volatiles from ocean island volcanoes: Insights from El Hierro, Canary Islands. Geochimica et Cosmochimica Acta 258: 19-36.

Wang J., Xiong X., Takahashi E., Zhang L., Li L., Liu X. (2019). Oxidation State of Arc Mantle Revealed by Partitioning of V, Sc and Ti Between Mantle Minerals and Basaltic Melts. Journal of Geophysical Research: Solid Earth 124: 4617-4638.

Waters C. L., Day, J. M. D., Watanabe, S., Sayit, K., Zanon, V., Olson, K. M., Hanan, B. B., Widom, E. (2020). Sulfide mantle source heterogeneity recorded in basaltic lavas from the Azores. Geochimica et Cosmochimica Acta 268: 422-445.

Waters L. E. and Lange R. A. (2016) No effect of $\mathrm{H}_{2} \mathrm{O}$ degassing on the oxidation state of magmatic liquids. Earth Planet. Sci. Lett. 447, 48-59.

Wood B. J., Walter M. J., Wade J. (2006). Accretion of the Earth and segregation of its core. Nature, 441(7095): 825-833. 
Workman R. K., Hart S. R. (2005). Major and trace element composition of the depleted MORB mantle (DMM). Earth and Planetary Science Letters 231: 53-72.

Workman R. K., Hart S. R., Jackson M., Regelous M., Farley K. A., Blusztajn J., Kurz M., Staudigel H. (2004). Recycled metasomatized lithosphere as the origin of the Enriched Mantle II (EM2) endmember: evidence from the Samoan volcanic chain. Geochem. Geophys. Geosys. 5(4): 1-44.

Williams H. M., Bizimis M. (2014). Iron isotope tracing of mantle heterogeneity within the source regions of oceanic basalts. Earth and Planetary Science Letters 404: 396-407.

Woodhead J. D. (1996) Extreme HIMU in an oceanic setting: the geochemistry of Mangaia Island (Polynesia), and temporal evolution of the Cook-Austral hotspot. Journal of Volcanology and Geothermal Research 72: 1-19.

Zhang H. L., Cottrell E., Solheid P. A., Kelley K. A., Hirschmann M. M. (2018) Determination of $\mathrm{Fe}+/ \Sigma \mathrm{Fe}$ of XANES basaltic glass standards by Mössbauer spectroscopy and its application to the oxidation state of iron in MORB. Chemical Geology 479: 166-175.

Zindler A., Hart S. (1986) Chemical Geodynamics. Ann. Rev. Earth Planet. Sci. 14: 493-571. 
Figure 1

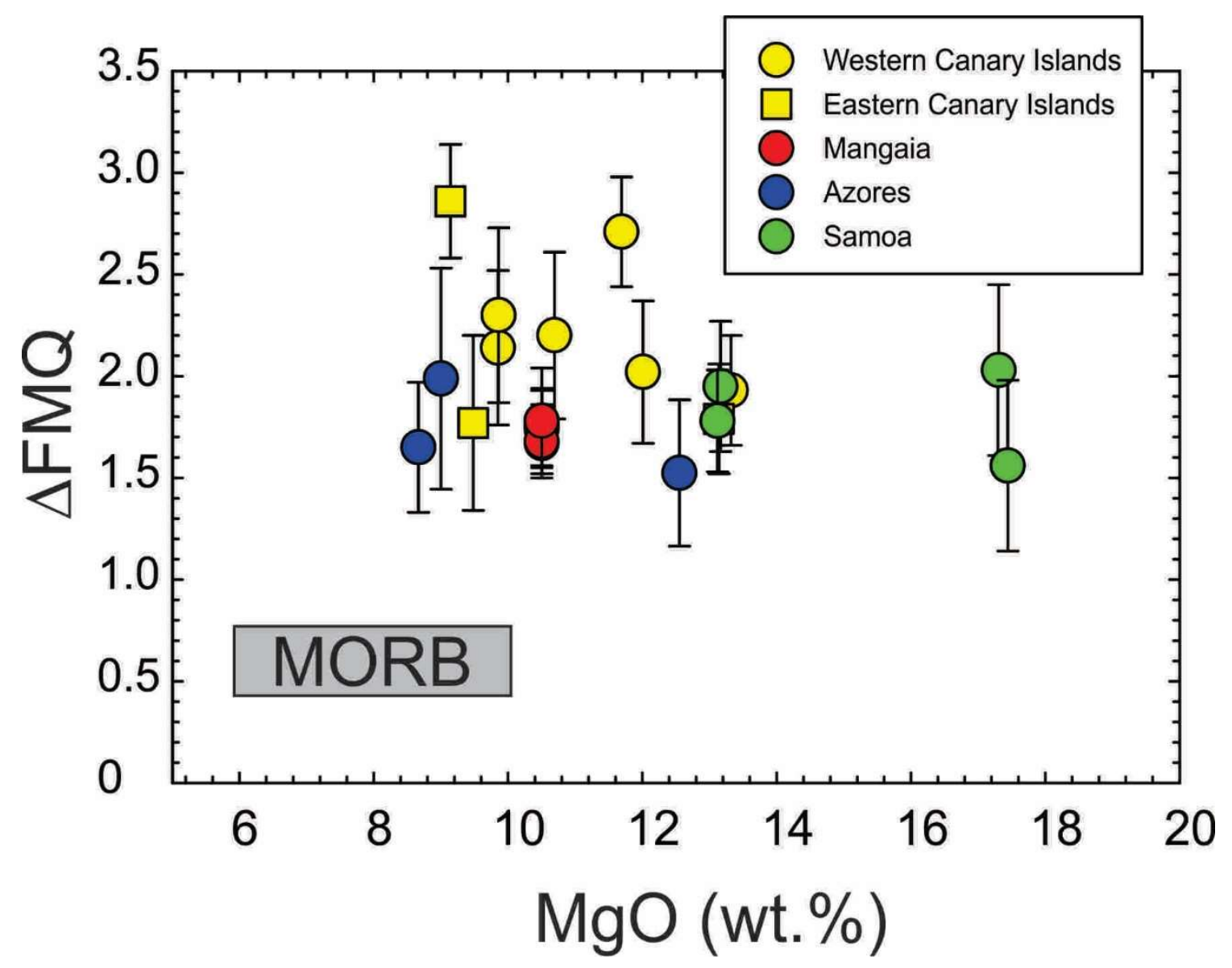


Figure 2

Figure 3.



